Edith Cowan University

Research Online

ECU Publications 2011

$1-1-2011$

\title{
The relationship between water, health and global environmental change, as interpreted through five key Multilateral Environmental Agreements (MEAs)
}

Pierre Horwitz

Edith Cowan University

Lucilla Spini

Kathryn Campbell

R J Thomas

Jo Mulongoy

Follow this and additional works at: https://ro.ecu.edu.au/ecuworks2011

Part of the Environmental Sciences Commons

10.1016/j.cosust.2011.10.001

This is an Author's Accepted Manuscript of: Horwitz, P. , Spini, L., Campbell, K., Thomas, R., \& Mulongoy, J. (2011).

The relationship between water, health and global environmental change, as interpreted through five key

Multilateral Environmental Agreements (MEAs). Current Opinion in Environmental Sustainability, 3(6), 520-526.

Available here

This Journal Article is posted at Research Online.

https://ro.ecu.edu.au/ecuworks2011/561 


\title{
The relationship between water, health and global environmental change, as interpreted through five key Multilateral Environmental Agreements (MEAs)
}

\author{
Pierre Horwitz' ${ }^{1}$ Lucilla Spini², Kathryn Campbell ${ }^{3}$, R.J. Thomas² and Jo Mulongoy ${ }^{3}$ \\ 'Consortium for Health and Ecology, Edith Cowan University, Western Australia \\ 2 United Nations University-Institute for Water, Environment and Health, Ontario, Canada \\ 3 UN Convention on Biological Diversity, Montreal, Canada
}

\begin{abstract}
For five Multilateral Environmental Agreements (MEAs), we have examined the way the relationship between water, health and global environmental change is expressed and how it has evolved recently. We recognize a distinction between an emphasis on water and reservoirs of water for health (for drinking water supplies, sanitation and hygiene), and a focus on places of water, where wetland ecosystems provide a service for human well-being which encompasses health. We also recognize a trend over time for the MEAs to increasingly address water, health and global change issues as a reaction to emerging infectious diseases and global pandemics. For both observations we note an increasing reliance on collaborative efforts across the MEAs, and beyond to involve international food, agriculture, trade and health sectors, and the emergent theme on ecosystem approaches to human health.
\end{abstract}

\section{Introduction}

The connection between human health and well-being, and access to sufficient drinking water, has long been recognized. Indeed, water is one of four elemental features that unify life (water, air, earth and fire) and for humans water is meaningful for everything from physiology to spirituality. Public health and epidemiology were founded on the concept of waterborne diseases, and the nature of human exposure to bacteria in polluted waters has driven the mandate for sanitation and hygiene, still important throughout the world today. Perhaps in the often frenetic attempts to maintain or to attain sanitation and hygiene the role of ecosystems in mediating the relationship between water and human health has been pushed into the background.

The relationships demand a global response; one to address widespread localised inequities and health issues as expressed by attempts to achieve the Millennium Development Goals (MDGs), and one to confront and respond to risks of global change, from climate change to depleting resources like fisheries and forests, declines in biodiversity, increasingly degraded wetland ecosystems and growing sources of pollution. While the project of modernity would ordinarily seek to rest such risks on the shoulders of nation states, there is an assumption that appropriate responses can only be dealt with across the globe, in forums where, for instance, the governments of nation states commit to collective action.

MEAs - including international conventions - are amongst those forums where governments can address issues related to the global common in a concerted action. In this context, MEAs are appropriate venues to address the interface between the environment and health, at the transboundary level and within the framework of global environmental change. This paper seeks to describe and interpret the way a selected sample of MEAs have constructed the relationship between water, health and global environmental change. 
We have chosen five international Conventions: the Ramsar Convention on Wetlands (Ramsar, Iran, 1971); the Convention on the International Trade of Endangered Species (CITES, 1973); the Convention on Migratory Species (CMS, 1979); the Convention on Biological Diversity (CBD, 1992); and the United Nations Convention to Combat Desertification (UNCCD, 1994). The selection allows for comparing Rio (CBD and UNCCD) and non-Rio (CITES, CMS, Ramsar) conventions, as well as species-focused (CITES and CMS) and ecosystem/thematic-focused (CBD, Ramsar, and UNCCD) agreements. It is preliminary in the sense that it may be used as the basis for a more comprehensive review and analysis across a broader set of international Conventions including prominent and relevant ones such as the United Nations Framework Convention on Climate Change (UNFCCC) and the Chemicals and Waste Management Conventions (e.g. The Stockholm Convention on Persistent Organic Pollutants).

For each of the five above-mentioned Conventions, we aimed to examine the way the relationship between water, health and global environmental change is expressed in the wording of the Convention and how it has evolved in its most significant instruments. This was undertaken through a review of adopted documents (e.g., Decision, Resolutions) and related materials (e.g., reports, publications). Keyword searches in review materials for 'water', 'health' and 'disease' helped pinpoint key expressions of the relationship. Relevant significant activities or programmes are also highlighted for each Convention.

\section{The Convention on the Conservation of Migratory Species of Wild Animals (CMS, 1979)}

The CMS (also known as the Bonn Convention), a biodiversity-related Convention signed in 1979, aims to conserve terrestrial, aquatic and avian migratory species throughout their range by promoting international cooperation among the Range States of many of these species. It acts as a framework Convention to speciesfocused agreements (e.g., Agreement on the Conservation of African Eurasian Migratory Waterbirds (AEWA)). However, this review focuses primarily on the framework Convention.

The text of the Convention does not refer explicitly to human health (nor to human well-being nor wildlife diseases/health). Furthermore no explicit reference was made to health/diseases in the first decade of the implementation of the Convention.

References to diseases and climate change are found in the text of Resolution 6.3, adopted in 1999. ("Aware that albatrosses also face continuing threats from human disturbance, pollution, introduced predators, disease and the effects of climate change;"), but no link is made to human health nor to the water/health nexus. In the text of Resolution 7.3 addressing oil pollution and migratory species, no reference is explicitly made to "health" and not even to "diseases"; here the linkages between water/health and global change "could have been expected"; but it only refers to, for example, "hazards" and "negative impacts".

It is only in the 2000s that the relationship becomes more explicit; in 2004, while it was not an official document of the Convention, the CMS's 25th Anniversary Booklet's cover states, inter alia: "In many cases migratory animals are essential to the health of ecosystems and to human well-being."; further reference to linkages between human and animal health are found throughout the booklet.

A more formal shift in the Convention towards focusing on health, and the linkages between water, health and global environment change, can be associated with concerns about the role of migratory birds as potential vectors of Highly Pathogenic 
Avian Influenza (HPAl) virus subtype H5N1. This issue involved CMS (with the AEWA), the Food and Agriculture Organization of the UN (FAO of the UN), and the Ramsar Convention (see Cromie et al. in press for a history of MEA involvement), and resulted in significant Resolutions that made explicit the linkages between health (human and wildlife health), wetland ecosystem and global changes processes (e.g., Resolution 8.27 on Migratory Species and Highly Pathogenic Avian Influenza adopted in November 2005). Also important to highlight here is the establishment of the Scientific Task Force on Avian Influenza and Wild Birds in August 2005.

This shift is further reflected in the CMS Strategic Plan 2006-2011 referring to "global change processes" (including climate change; Section 2.3.8-9) that are increasing threats to migratory species, and referring to ecosystem health and the well-being of human populations that depend on migratory animals for their livelihood (Section 2.4.12); as well as in Resolution 9.8 (adopted in 2008, and also calling for the establishment of a Scientific Task Force - co-convened by CMS and FAO of the UN on Wildlife Diseases) as can be seen in its preamble. The relationship between water and health and global environmental change is best exemplified by the recognition given to the role of wetland ecosystems in the 'natural' epidemiology of avian influenza, in Appendix 1 of the same resolution.

The above-mentioned Scientific Task Force on Wildlife Disease has as its main aim the identification of diseases that impact domestic and migratory wildlife and are of concern to food security, sustainable livelihoods and conservation. It is expected to be fully operational by the end of 2011.

\section{The Convention on International Trade in Endangered Species of Wild Fauna and Flora (CITES, 1973)}

CITES, a biodiversity-related Convention signed in 1973, seeks to ensure that international trade in specimens of wild animals and plants does not threaten their survival. International wildlife trade is diverse, ranging from live animals and plants to a vast array of wildlife products derived from them. Many wildlife species in trade are endangered, others are not; the existence of an agreement to ensure the sustainability of the trade is important in order to safeguard these resources for the future.

The relationship between water, health, and global environmental change does not appear in the text of the Convention as such. Instead it might be regarded as implied, since water, health and global environmental change can each be seen. The concept of 'health' is used in Article IV in the sense of "to minimize the risk of injury, damage to health or cruel treatment". This manifests as a regard for the health care of individuals, or the effects of disease on individuals and species as a whole. 'Global environmental change' is recognized, for example, as a series of extrinsic factors that need to be considered for amendments to Appendices of the Convention (Conf. 9.24 (Rev. CoP15)).

Human health is indirectly implicated in two ways. The trade and transportation of animals can generate risks from disease exchange between wild species and humans. An example is where unregulated trade in and consumption of "bushmeat" may bring risks to human health by increasing the proximity of humans and wild animals, influencing disease spread (CITES COP15 Inf. 19).

The second way is that traditional medicines derived from species are important for improving human health outcomes, acknowledging the importance of traditional medicines to the world's medicinal security, that millions of people depend on these medicines for primary health care, and that the problems of over-exploitation of 
certain wild species need to be addressed (Conf. 10.19 (Rev. CoP14)). The latter implication is also evidenced by the exemptions to the Convention under circumstances of the imperative for public health; trade is allowable to develop products to promote public health, and where the "sale is incidental to public health" (and "public health research") and "not for the primary purpose of economic benefit." (Conf 5.10 (Rev. CoP15)).

The relationship between human health and global environmental change for the Convention therefore hinges on the connections made firstly between the trade of plants or animals and the destruction of their habitat in the wild, and secondly on the way human health might be implicated either through disease transmission or loss of traditional or commercially-derived medicinal or pharmaceutical products for health care.

Regarding water, most instances of the Convention where reference is made to water related to the habitat of the wild species, and the requirement for water in captivity or transportation of the species. Where the species of concern for CITES have a particular requirement for water (as aquatic habitat), hydrological alterations due to global environmental change is relevant. It is feasible that hydrological change, habitat alteration and disease transmission or loss of a medicinal product might be relevant for human health where the trade of species is implicated, and where the Convention might be invoked.

\section{Ramsar Convention on Wetlands (Ramsar, 1971)}

The Ramsar Convention, a biodiversity-related Convention agreed and signed in Iran in 1971, encompasses the scope of wetlands and water, and ecosystems and people. In its original text, recognition of "the interdependence of man and his environment" was apparent, even though the initial focus of wetland conservation in the early 1970s was on conserving habitat for waterfowl and other charismatic wildlife, and designating Ramsar sites. Its three pillars of implementation are the "wise use" of all wetlands, the designation and management of Wetlands of International Importance (Ramsar sites) to maintain their ecological character, and international cooperation.

In its 40 years, the Convention has increasingly focussed on the intrinsic links between wetland ecosystems and wetland dependent people; indeed it has been something of a progression towards the adoption of a coherent articulation of the relationship between water, health and global environmental change. The text recognises that "wetlands constitute a resource of great economic, cultural, scientific, and recreational value, the loss of which would be irreparable"; and "the fundamental ecological functions of wetlands as regulators of water regimes".

The Ramsar Convention focus of wetland management has been to ensure "wise use", defined as "the maintenance of ecological character, achieved through the implementation of ecosystem approaches, within the context of sustainable development" (Ramsar Convention Secretariat 2005). The Convention further defines ecological character as the "combination of the ecosystem components, processes and benefits/services that characterise the wetland at a given point in time". Change in ecological character is the human-induced adverse alteration of any ecosystem component, process, and/or ecosystem benefit/service.

At the $9^{\text {th }}$ meeting of the Conference of the Parties (COP) to the Ramsar Convention (Ramsar 2005b), Resolution IX.2 instructed its Scientific and Technical Review Panel (STRP) as an immediate priority task to undertake a review of the issues and 
interactions between wetlands and human health. This topic subsequently attained further significance with the adoption of the theme for COP10 in 2008 as "Healthy Wetlands, Healthy People". The resulting work of the STRP characterized wetland ecosystems as settings that determine human health and well-being through a number of influences (Figure 1).

It was important for the Convention to argue that these influences can either enhance or diminish human health depending on the ecological functioning of wetlands, and their ability to provide ecosystem services. It follows then that losses of wetland components, and disruptions to wetland functions and ecosystem services will have consequences for human health along any or all of these lines. Furthermore, adverse health outcomes are likely to be distributed in an unequal way, along socio-economic lines, and management interventions for wetlands must also seek to address these inequities (Horwitz et al. 2011).

\section{The Convention on Biological Diversity (CBD, 1992)}

The CBD, one of three Rio Conventions and a biodiversity-related Convention, was opened for signature in 1992. It has three main objectives: 1) the conservation of biological diversity 2) the sustainable use of its components, and 3) the fair and equitable sharing of the benefits arising out of the utilization of genetic resources.

The text of the Convention recognizes that conservation and sustainable use of biological diversity, including the control of living modified organisms, is of critical importance for meeting the food, health and other needs of the growing world population, as stated in the Preamble of the text.

The Conference of the Parties (COP), which is the Convention's governing body, has adopted seven thematic programmes of work over the last 15 years that provide guidance on implementation of the Convention in the major biomes on the planet and established cross-cutting issues that provide links between thematic programmes (see Table 1). Water is an element in many of the thematic programmes of work and it is interesting to note that CBD COP delegated at its third meeting lead implementation partner status to the Ramsar Convention for inland water biodiversity. Health is not identified as a specific cross-cutting issue. Aspects of the complex relationships between water, health and biodiversity are becoming integrated within these programmes of work and cross-cutting issues (Table 1).

More recently, the $10^{\text {th }}$ Conference of the Parties (COP 10) meeting adopted a revised and updated Strategic Plan for Biodiversity 2011 - 2020 and 20 Aichi Biodiversity Targets (2020 Targets). The Plan's vision clearly acknowledges that biodiversity underpins ecosystem functioning and human well-being. The vision states that "By 2050, biodiversity is valued, conserved, restored and wisely used, maintaining ecosystem services, sustaining a healthy planet and delivering benefits essential for all people". Of the 2020 Targets, at least six have relevance to human health (Targets 1, 2, 11, 14, 17, 19), with Target 14 specifically addressing health, water and global environmental change: "By 2020, ecosystems that provide essential services, including services related to water, and contribute to health, livelihoods and well-being, are restored and safeguarded, taking into account the needs of women, indigenous and local communities, and the poor and vulnerable". These targets give impetus to the development of matching indicators for use in reporting at the national level.

This increasing importance of considering an interdisciplinary, collaborative approach to health was recognized at COP 10 in specific decisions. The Parties adopted a total of 16 decisions that make reference to human health/well-being in 
the context of $4 \mathrm{CBD}$ Programmes of Work and $7 \mathrm{CBD}$ cross-cutting issues. For example, decision X/20 (Cooperation with other conventions and international organizations and initiatives), paragraph 17 (in summary) requests the Secretariat to: (a) to further strengthen collaboration with the World Health Organization (WHO) as well as other relevant organizations to promote the consideration of biodiversity issues in health programmes; (b) to investigate how implementation of the Strategic Plan for Biodiversity 2011 - 2020 can best support efforts to address global health issues and in support of the MDGs; and (c) to explore avenues for bridging the gaps between work to address the impacts of climate change on public health and work to address the impacts of climate change on biodiversity.

In adopting the Biodiversity Strategic Plan, Parties noted that water can be regarded as a primary global natural resource challenge and a key link between the various MDGs and biodiversity. This highlights the relevance of water and ecosystem services provided by biodiversity to sustainable human development including human health, poverty reduction, gender equity and climate change mitigation and adaptation.

\section{United Nations Convention to Combat Desertification (UNCCD, 1994)}

The objective of the United Nations Convention to Combat Desertification (UNCCD), a Rio Convention opened for signature in 1994, is to combat desertification and mitigate the effects of drought in countries experiencing serious drought and/or desertification, particularly in Africa. It operates within a framework of 'an integrated approach, with a view to contributing to the achievement of sustainable development in affected areas' (UNCCD 1992). The convention thus encourages multi-disciplinary approaches to desertification and drought through long-term integrated strategies that focus on improved productivity of land, and the rehabilitation, conservation and sustainable management of land and water resources, leading to improved living conditions, in particular at the community level (UNCCD 1994).

The text of the Convention notes that desertification/land degradation and drought (DLDD) "is caused by complex interactions among physical, biological, political, social, cultural and economic factors", and is interrelated with "social problems such as poverty, poor health and nutrition, lack of food insecurity" and other factors (UNCCD 1994). The Convention explicitly recognizes that it can contribute to, and should interact with, the two other Rio Conventions and other international agreements and should develop joint programmes, particularly in the fields of research, training, systematic observation and information collection and exchange (Article 8 UNCCD). Unfortunately while joint work programmes and MOUs between UNCCD and other MEAs are available (Chasek et al, 2011) there are few examples of such interactive programmes.

Parties to the convention plan and implement national, sub-regional and regional action programmes that utilize and build on existing relevant plans and programmes such as Poverty Reduction Strategies (Article 9 UNCCD). These plans should address the specific needs of local populations and lead to the identification and implementation of solutions that improve the living standards of people in affected areas including the availability of water resources (Article 17 UNCCD).

While the Convention's articles have just one reference to 'poor health' the focus on water availability is associated with water scarcity in dry areas and hence limited levels of sanitation and large amounts of time and energy in seeking and 
transporting water for domestic and animal use. For example many of the 2.6 billion people who lack access to improved sanitation live in dry areas and $70 \%$ live in rural areas (WHO/UNICEF 2010). If achieved, access to clean water can reduce water borne disease by at least $25 \%$, while improved sanitation can result in a $30 \%$ reduction in child mortality (Schuster-Wallace et al. 2008). Conversely, a season of particularly high rainfall (in areas of DLDD) may contaminate water sources as well as the population dynamics of host, vector or reservoir species, increasing the risk of vector- and water-borne diseases.

Finally, the UNCCD cites the need for "development of sustainable irrigation programmes for both crops and livestock" (UNCCD, 1994). Dams and irrigation systems, in the effort to increase food production and provision of water to cultivated areas and rangelands, have also led to the emergence and spread of some infectious diseases by providing ecological niches for vector and reservoir species and altering microclimates.

\section{Discussion}

We recognize that our analysis is limited in focus by choosing only five MEAs and preliminary by nature; a complete analysis would treat the texts of other global MEAs (including the UNFCCC and the Chemicals and Waste Management Conventions), those of international organizations (e.g. FAO of the UN, the World Health Organization (WHO), and the World Organisation for Animal Health (OIE)), and regional MEAs (e.g., Protocol on Water and Health to the Convention on the Protection and Use of Transboundary Watercourses and International Lakes).

Nevertheless, the patterns by which these five MEAs have engaged with the relationship are instructive, and would be, we hypothesize, reflected in more comprehensive treatment of the MEAs and other international instruments and fora.

We recognize a distinction between an emphasis on water and reservoirs of water (for drinking water supplies, sanitation and hygiene), and a focus on the places of water, where wetland ecosystems provide a service (like 'green infrastructure') for the provision of water and livelihoods. While the first approach is the one addressed by the pan-European Protocol on Water and Health, the latter was particularly evident in the Ramsar Convention's trajectory, one that contributed to the influential work of the Millennium Ecosystem Assessment (Ecosystems and Human Well-being), and in the CBD and CMS approaches. The Ramsar Convention in this and subsequent work has arguably reconnected the health sector, the water sector and issues of global environmental change from the perspectives of wetland ecosystem services.

We highlight that the trends in explicitly addressing "health" within these environmental agreements can be considered a reflection of global actions/declarations on environment and development; for instance, more explicit reference to "health" in the Rio Conventions (in the CBD especially) may be related to the fact that Principle 1 of the Rio Declaration on Environment and Development (UNCED) states "Human Beings are at the centre of concerns of sustainable development. They are entitled to a healthy and productive life in harmony with nature". Furthermore we recognize historical trends in approaching the water/health and global changes linkages within the Ramsar, CMS, CBD and to a certain extent CITES, with a period of more increased attention in the first decade of the 2000s. This period of activity can probably be linked to other international exercises such as the WEHAB (Water, Energy, Health, Agriculture and Biodiversity) and the Millennium Ecosystem Assessment as well as the Millennium Declaration and 
MDGs. It is important to recall here the document "A Framework for Action on Health and Environment" (WEHAB Working Group, August 2002), in which the biodiversity conventions (including those examined here) are not listed as relevant agreements.

However, the main trigger for MEAs to address water/health and global change issues can be identified in reaction to emerging infectious diseases and global pandemics (but not environmental disasters such as oil spills) threatening both human and animal health; this can be particularly seen in the CMS and perhaps to a lesser extent CITES. Indeed, the absence of explicit linkages between water and health (related to wetlands-water-birds) in the early years of the CMS may be related to the focus of the Ramsar Convention on Wetlands in the 1970s/1980s (and other international programmes, such as the Man and the Biosphere (MAB) Programme, addressing human-nature through a more integrated and holistic approach). Again, Ramsar's significance was acknowledged by the CBD's delegated partnership role. The CBD's articulation of the strategic link of water in the achievement of the MDGs and biodiversity conservation is a beacon for the relationship.

Overlapping agendas among MEAs, particularly for human health and well-being have made the imperative of collaborative efforts between them clearer; examples of this collaboration include the Millennium Ecosystem Assessment project, cooperation across the Biodiversity-related conventions on scientific, technical and technological matters associated with cross-cutting themes such as water and wetlands, and global environmental change, and the response to highly pathogenic avian influenza. Indeed these collaborative efforts are highlighting a global agenda that integrates an ecosystem approach with the health of animals and the health of humans.

Many of the possible response options for addressing ecosystem change and human well-being lie primarily outside the direct control of the environment sector writ large, or even the health sector. Instead they are embedded in areas such as sanitation and water supply, education, agriculture, trade, tourism, transport, development, and housing. Inter-sectoral and cross-sectoral integrated options are therefore needed to reduce the potential health impacts of ecosystem change. In this regard, it is important to identify the principal cross-sectoral partners and responsible stakeholder groups required to achieve appropriate outcomes. International initiatives on health and environment (e.g., the Canadian Government's International Development Research Centre (IDRC) Ecohealth programme, the International Association for Health and Ecology, and the Global Environmental Change and Human Health (GECHH) Joint Project of the Earth System Sciences Partnership (ESSP)) as well as organizations working on the water/health nexus (e.g., United Nations University Institute for Water, Environment and Health (UNU-INWEH) and the International Water Management Institute ( IWMI)) have emerged as key mediating organizations to enable these collaborations. The findings of this brief review indicate a fertile area of activity for intergovernmental organizations and partners: to develop, more substantively, ecosystem approaches to human health (sensu Waltner-Toews 2001) as a cross-cutting theme applicable to MEAs. 
Table 1: Table of the Convention on Biological Diversity's 7 Thematic Programmes of Work and 20 Cross-cutting Issues. An asterisk* indicates a cross-cutting issue where the relationship between any or all of biodiversity, water, human health, and global environmental change can be considered. For further information see: http://www.cbd.int/programmes/.

\section{Thematic Programmes of Work}

Agricultural Biodiversity

Dry and Sub-humid Lands

Biodiversity

Forest Biodiversity

Inland Waters Biodiversity

Island Biodiversity

Marine and Coastal

Biodiversity

Mountain Biodiversity

\section{Cross-cutting Issues}

Aichi Biodiversity Targets*

Genetic Resources and

Benefit-sharing*

Biodiversity for

Development*

Climate Change and

Biodiversity*

Communication, Education

and Public Awareness

Economics, Trade and

IncentiveMeasures

Ecosystem Approach*

Gender and Biodiversity*

Global Strategy for Plant

Conservation

\author{
Global Taxonomy Initiative \\ Impact Assessment* \\ Identification, Monitoring, \\ Indicators and Assessments \\ Invasive Alien Species* \\ Liability and Redress - Art. \\ 14 (2) \\ Protected Areas* \\ Sustainable Use of \\ Biodiversity \\ Tourism and Biodiversity \\ Traditional Knowledge, \\ Innovations an Practices - \\ Article $8(j)$ * \\ Technology Transfer and \\ Cooperation
}

\section{Figure 1.}

The Ramsar Convention's STRP characterized wetland ecosystems as settings that determine human health and well-being through a number of influences (adapted from Horwitz et al. 2011):

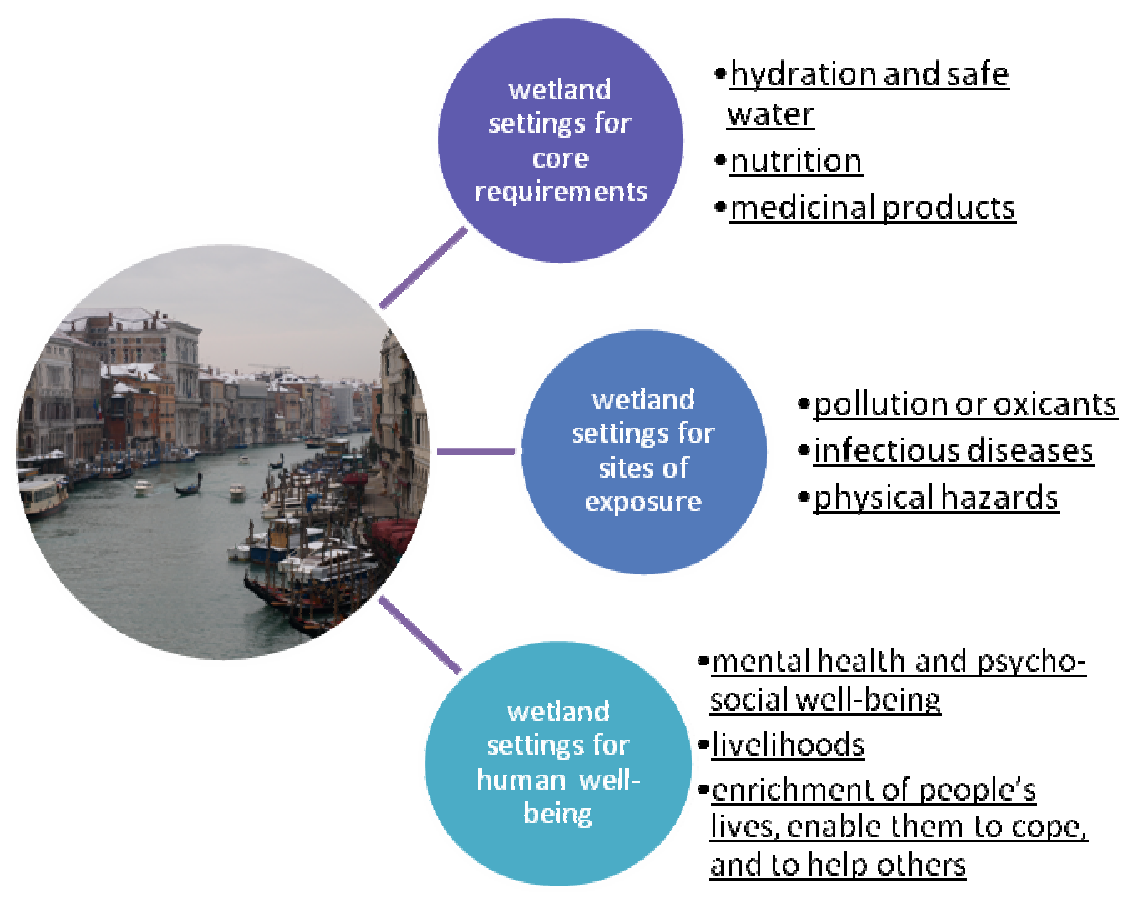





\section{Annotated Bibliography}

1. *Chasek, P., Essahli, W, Akhtar-Schuster, M, Stringer, LC, Thomas, R. (2011). Land degradation and Development 22, 272-284. A brief version of a Table and discussion of joint agreements can be found in the White Paper of DSD Working Group 3 Monitoring and assessment of desertification and land degradation: knowledge management, institutions and economics. Akhtar-Schuster, M, Bigas, H, Thomas, R. (eds). Available at http://www.inweh.unu.edu/publications. htm.

2. ${ }^{*}$ Chivian, E. and Bernstein, A. (2008). Sustaining Life: How Human Health Depends on Biodiversity, Oxford University Press

3. *Convention on Biological Diversity (1992). Text of the Convention at http://www.cbd.int/doc/legal/cbd-en.pdf

4. *Convention on Biological Diversity (2010). Strategic Plan 201 1-2020. http://www.cbd.int/sp/

5. ${ }^{* *}$ Cromie, R., Davidson, N., Galbraith, C., Hagemeijer, W., Horwitz, P., Lee, R., Mundkur, T. \& Stroud, D.A. (in press). Responding to emerging challenges: Highly Pathogenic Avian Influenza H5N1, and the response of the Ramsar Convention and other MEAs. Journal of International Wildlife Law \& Policy. A history of the way a selection of MEAs responded to the highly pathogenic avian influenza virus H5N1.

6. **Horwitz, P., Finlayson, M. and Weinstein, P. (201 1). Healthy wetlands, healthy people. A review of wetlands and human health interactions. Secretariat of the Ramsar Convention on Wetlands and the World Health Organisation. Ramsar Technical Report No. 6. Gland, Switzerland.

7. *Schuster-Wallace, CJ, Grover, W, Adeel, Z, Confalonieri, U, Elliott, S. 2008. Safe water as the key to global health. UNU-INWEH, Hamilton, Canada. Available at http://www.inweh.unu.edu/publications.htm.

8. Secretariat Convention Biological Diversity (2010) Good Practice Guide: Drinking Water, Biodiversity and Development available at http://www.unwater.org/wwd10/downloads/cbd-good-practice-guide-wateren.pdf

9. UNICEF and WHO (2010). Joint Monitoring Programme for Water Supply and Sanitation (JMP) 2010. Progress on sanitation and drinking water , 2010 update. Available from http://www.wssinfo.org/resources/documents.html

10. United Nations Convention on Combating Desertification (1994). United Nations Convention to Combat Desertification in Those Countries Experiencing Serious Drought and/or Desertification Particularly in Africa: Text with Annexes. United Nations: New York. Text of the Convention. In particular articles 8, 9 and 17 of the convention spell out the range of activities to be undertaken by affected countries. Articles of the convention are available at http://www.unccd.int/convention/text/convention.php

11. United Nations Environment Programme (UNEP) / Convention on International Trade in Endangered Species of Wild Fauna and Flora. Text of the Convention at http://www.cites.org/ 
12. United Nations Environment Programme (UNEP) / Convention on International Trade in Endangered Species of Wild Fauna and Flora (2008?) Conf. 10.19 (Rev. CoP14) Traditional medicines.

13. * United Nations Environment Programme (UNEP) / Convention on International Trade in Endangered Species of Wild Fauna and Flora (2006?) Conf. 13.4 Conservation of and trade in great apes. Shows how the issues of human health, animal health and global environmental change are inter-related.

14. United Nations Environment Programme (UNEP) / Convention on International Trade in Endangered Species of Wild Fauna and Flora. (2010) Conf. 5.10 (Rev. CoP15) Definition of 'primarily commercial purposes'.

15. United Nations Environment Programme (UNEP) / Convention on International Trade in Endangered Species of Wild Fauna and Flora (2010). Letter of Understanding Establishing the International Consortium on Combating Wildlife Crime http://www. cites.org/eng/news/press/2010/ICCWC_memo.pdf

16. **United Nations Environment Programme (UNEP) / Convention on International Trade in Endangered Species of Wild Fauna and Flora (2010). Conf. 9.24 (Rev. CoP 15) Criteria for amendment of Appendices I and II). Includes a list of extrinsic factors (global environmental change) that are responsible for vulnerability, including threats from alien invasive species (hybridization, disease transmission, depredation, etc., habitat degradation, loss/destruction, fragmentation, threats from disease, rapid environmental change (e.g. climate regime shifts), and stochastic events.

17. United Nations Environment Programme (UNEP) / Convention on Migratory Species (CMS), 2004. 25 Years of Journeys - A special report to mark the Silver Anniversary of the Bonn Convention on Migratory Species (1979-2004),

http://www.cms.int/news/PRESS/nwPR2004/25th_Anniversary/CMS_Bulletin_25th_Ann en.pdf

18. ${ }^{*}$ United Nations Environment Programme (UNEP) / Convention on Migratory Species (CMS), 2006. Migratory species and climate change : impacts of a changing environment on wild animals, http://www.cms.int/publications/pdf/CMS_CimateChange.pdf This publication delivers comprehensive overview of the work of the CMS concerning climate change and migratory species.

19. **United Nations Environment Programme (UNEP) / Convention on Migratory Species (CMS) 2007._Proceedings of the 2nd Technical Meeting of the Scientific Task Force on Avian Influenza \& Wild Birds, Avian Influenza \& Wildlife Workshop on 'Practical Lessons Learned', Aviemore, Scotland: 26 - 28 June 2007, http://www.cms.int/publications/pdf/Avian_Influenza/Aviemore_U1U2U3U4_NEU. pdf This publication provides further information on the role and activities of the Task Force on Avian Influenza and Wild Birds. The related website www. aiweb.info is another important source of information and publications.

20. * United Nations Environment Programme (UNEP) / Convention on Migratory Species (CMS), 2009. CMS Family Guide - Third Edition, http://www.cms.int/publications/family guide.htm This Guide describes the history, structure, mechanisms and documents, species coverage of the Convention on Migratory Species (CMS), as well as information on threats and 
challenges affecting migratory species (e.g., climate change, oil spills, and avian influenza).

21. United Nations Environment Programme (UNEP) / Convention on Migratory Species (2005). Convention on Migratory Species Strategic Plan 2006-201 1. UNEP/CMS/Resolution 8.2. United Nations Environment Programme. Adopted by the COP in 2005, refers to "global change processes" in paragraph 2.3.8-9 (page 3) and in the logical framework (Section 6) refers to climate change and disease.

22. ${ }^{*}$ United Nations Environment Programme (UNEP) / Convention on Migratory Species (2008). Responding to the challenge of emerging and re-emerging diseases in migratory species, including highly pathogenic avian influenza H5N1. UNEP/CMS/Resolution 9.8. United Nations Environment Programme. A particularly succinct preamble in the context of this paper: "Noting that the increased frequency of such diseases has been linked to processes of landscape fragmentation, unsustainable land-use choices, pollution and other types of ecosystem disruption, these being, in turn, the consequences of unsustainable pressure on resources as highlighted by the Millennium Ecosystem Assessment; and further noting that climate change is expected to result in changes in disease distribution and emergence due to altered physiological conditions for hosts and parasites, resulting in the spread of novel micro-organisms with unpredictable consequences or the re-emergence of pathogens in new geographic locations;". Also includes as Appendix 7 "Scientific summary of highly pathogenic avian influenza H5N1: wildlife conservation consideration" where the role of wetlands in the epidemiology of the disease are mentioned.

23. *Waltner-Toews, D. (2001). An ecosystem approach to health and its applications to tropical and emerging diseases. Cad. Saúde Pública 17, S7-S36. One of the earliest and still one of the more coherent formulations of the need for systems thinking and a consideration of the socio-ecological context when dealing with matters of human health, drawing attention to the role of community involvement and ecological awareness.

24. **WEHAB Working Group, August 2022 A Framework for Action on Health and Environment

http://www.un.org/ssummit/html/documents/summit_docs/wehab_papers/weha $\underline{b}$ health.pdf Key document highlighting issues and challenges, also including an overview of the major conferences and international agreements as well as UN System capacities related to environment and health. 